\title{
Work Life Balance And Job Satisfaction Of Lecturer In Faculty Of Economics And Business Unjani
}

\author{
Dian Lestari $^{1 *}$, Rahardianto ${ }^{2}$ \\ ${ }^{1,2}$ Management Study Program, Faculty of Economics and Business, Jenderal Achmad Yani \\ University, Indonesia. \\ * Corresponding author: \\ Email: dian.lestari@lecture.unjani.ac.id
}

\begin{abstract}
.
This study aims to determine the effect of work life balance on job satisfaction of lectures at Economy and Business Faculty, Universitas Jenderal Achmad Yani. Work life balance as independent variable consist of time balance, involvement balance and satisfaction balance. And the job satisfaction as dependent variable measured by psychological factors, social factors, physical factors and financial factors. This research was descriptive and verificative method. Questionnaires were distributed to the lectures of the Economy and Business Faculty, Universitas Jenderal Achmad Yani. Saturated sampling technique was used in this research. And the techniques of data analysis uses Descriptive Statistics and Simple Linier Regression. The results showed that work life balance positively effect job satisfaction of lectures at Economy and Business Faculty, Universitas Jenderal Achmad Yani. Work life balance has an effect on the job satisfaction of lectures by $31.8 \%$, while the rest was effected by other variables that is not examined in this research.
\end{abstract}

Keywords: work life balance, job satisfaction

\section{INTRODUCTION}

In a book written by [1], it was stated that at first the term work-life balance was better known as work-family balance. The shift in the term arises from the realization that childcare is not the only thing that is important outside of work responsibilities, but can also be applied to other activities or commitments, and can cover a wider variety of workers, both female and male workers, workers with children or no, workers who are married or unmarried. According to Hudson, other life activities that also need to be balanced with work life include education, recreation, sports, volunteering, personal development and leisure time.Work-life balance has many definitions and various explanations, according to [2] the balance of individuals in carrying out the dual roles they have in the world of work and personal is a work-life balance. [3] stated the same thing, "work life balance: balancing their work and personal lives", meaning that work-life balance means balancing life in the world of work and personal life.A similar definition was conveyed by [4] which stated that work-life balance is a condition of a person where he is able to create a balance for the demands of his work with other demands such as personal and family needs. [5] also define it in a similar way, namely the extent to which employees can balance their role in the world of work with life outside of work, this is what is called work-life balance. 
Another definition of work life balance is an individual who is able to fulfill work, commitments or family affairs, as well as other responsibilities outside of work [6].

Work life balance is closely related to individuals who have enough time to have a balance in work and personal life, such as being able to spend time with family members, free time to relax, communicate with colleagues, and be able to complete their work well [7]. [8] defines work life balance as a condition in which an individual can manage time well or can harmonize work, family life, and personal interests. [9] mentions work-life balance, a condition where workers feel they are able to fulfill their responsibilities by balancing work and commitments outside of work. [10] work-life balance is the capability of an individual to fulfill the duties of his job as well as demands from outside the work, and this makes the individual happy.From the various definitions above, work life balance is a condition where a person has a balance in living his life, both in terms of work, family interests and other personal interests so as to create a harmonious life. [11] mention that work-life balance includes: 1) Time balance, 2) Involvement balance, and 3) Satisfaction balance.[12] mention job satisfaction refers to how a person feels about his job. [13] mentions job satisfaction, namely the emotional response of an individual based on the values he feels in a job. [14] suggests job satisfaction is the emotional attitude of employees where they have a sense of pleasure and love for their work. This attitude is reflected in his work morale, work discipline and work performance he has achieved.

It is also mentioned that job satisfaction is a positive emotional expression of an employee as a result of his assessment of the work he has [15]. Another definition, job satisfaction is a positive feeling from an employee about his job that is obtained from his evaluation of the characteristics of a job [16].From the expert opinions above, job satisfaction is an emotional expression or feeling either positive or negative that an employee has towards his job, the result of an evaluation of the characteristics that exist in the job.According to [17] remuneration (fair and proper), accuracy in placing employees, workload, work environment and atmosphere, work equipment, attitude of superiors who become leaders, as well as variation or monotony of a job are factors that can affect job satisfaction. . Meanwhile, [18] states that job satisfaction can be influenced by, among others, the work itself, remuneration (salary), opportunities for promotion, supervision by the leader, and colleagues at work.The job satisfaction factors mentioned by the two experts above are not much different, namely related to compensation, type of work, work atmosphere and environment, working relationships between colleagues and superiors, and promotion opportunities.

All of these factors are included in the job satisfaction factor proposed by [19] namely: 1) Psychological factors, these factors are related to the psychology of an employee, such as interests, peace and tranquility when working, displayed attitudes, talents, and skills, 2) Social factors, this second factor is related to the communication (interaction) that occurs between employees and the leader (supervisor), 3) Physical factors, conditions related to employees physically, such as type of work, division of 
work and rest time, equipment for work, work space, air temperature, light, air circulation, physical health, age, and so on, and 4) Financial factors, related to the welfare of employees, such as the amount of salary, benefits, social security, facilities jobs, promotions, and so on.Many factors can affect job satisfaction, but in recent years work-life balance has become a factor that plays a significant role in achieving job satisfaction. From a survey conducted in 2014 by JobStreet.com on 17,623 correspondents about employee satisfaction at work, $73 \%$ of employees who are not satisfied with their work. The highest factor causing job satisfaction was not achieved, namely $85 \%$ of correspondents stated that they did not have a work life balance.

[20] states that workers who are able to balance work affairs with personal matters or other commitments they have, then have a good work-life balance. But in reality, the phenomenon that occurs is that many workers do not have this balance. [21] mention that most employees worldwide are under pressure to balance priorities between family and work. The demands of diverse work and the existence of work deadlines make lecturers certainly experience pressure and difficulty in realizing a balance of personal and work life, as a result work focus can decrease and lead to low job satisfaction.So the balance of work and personal life is one of the factors that need to be a concern for create job satisfaction. This makes the author compelled to research related to this matter, where in daily work-life balance is something that needs to be the attention of every worker. From this description, the author raises research about the effect of work life balance on job satisfaction of lecturers in Faculty of Economics and Business Unjani.The results of research conducted by [22] Qodrizana \& Musadieq (2018) show that the three dimensions of work life, namely time balance, involvement balance and satisfaction balance each have an effect on job satisfaction. Furthermore, research by [23] also states that work life balance has an effect on employee job satisfaction. In addition to the two studies above, research conducted by [24] also revealed that work life balance and work stress have a significant effect on the job satisfaction of educators.

The last research conducted by [25] explains that there is a positive and significant relationship between work life balance and job satisfaction. This study is not only to determine the effect of work-life balance on the job satisfaction of lecturers, but also to determine the condition of the lecturers' work life balance and job satisfaction in Faculty of Economics and Business Unjani. The information generated from the research is expected to be a consideration for institutions in managing their human resources by establishing policies that can support the work life balance of the lecturers, so that job satisfaction is achieved. Besides that, for the lecturers, research results can be used as a self-evaluation in setting priorities for activities and appropriate time management so as to create a balance of life. For students, they can receive the maximum and best output from the lecturers. The independent variable of this study is work-life balance, measured by the dimensions of time balance, balance of 
involvement, and balance of satisfaction [26] which will examine how it affects job satisfaction as the dependent variable, measured from psychological, social, and environmental factors. physical and financial [27]. The research model is as follows:

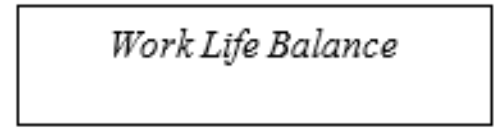

McDonald dan Bradley (2005)

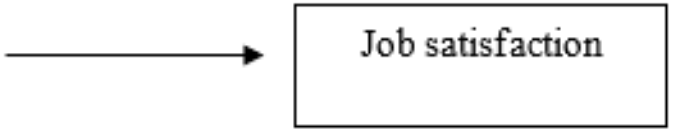

Sutrisne (2010)

Fig 1. Research Model

\section{METHODS}

\section{Research Design}

This research is included in descriptive and verification research, where descriptive research provides a description or description of the object being studied through samples or data collected as it is, which does not analyze and make valid conclusions [28]. So from this descriptive research, we get a picture of the balance of work and personal life as well as job satisfaction of the lecturers of the Faculty of Economics and Business Unjani. While the research method for testing research hypotheses from data collected in the field is a verification research. This verification study is to examine the effect of the independent and dependent variables in this study.

\section{Research Variables and Measurement Scale}

The research variables consist of one independent variable and the dependent variable each with the following details:

Work-life balance with three balances, including:

1. Time balance ; Related to the use of time by employees for work and for activities other than work, such as time for family and other activities such as doing hobbies, exercising, and so on.

2. The balance of involvement; Related to the psychological involvement of a person in the activities or work he does.

3. The balance of satisfaction Associated with the level of satisfaction of an individual both when doing work or when doing other activities outside of work. Job satisfaction is measured based on the following dimensions:

1. Psychological factors; This factor is related to the psyche in an employee, such as the interests he has, peace and tranquility when working, the displayed attitude, talents, and skills.

2. Social factors; This second factor is related to the interactions that occur between employees and supervisor.

3. Physical factors; the third is related to the physical condition of employees, such as equipment for work, working space conditions, air temperature or temperature, light or lighting, air circulation and so on.

4. Financial factors; related to employee security and welfare. 
For measuring respondents' answers, the measuring scale is the Likert scale, where according to [29] the scale is used related to measuring attitudes, perceptions (opinions) of a person or group regarding social phenomena. The alternative answers used in the questionnaire are five answer choices.

\section{Data Collection Techniques and Sampling Techniques}

Research data sourced from primary and secondary data. Primary data comes from data collected from distributing questionnaires and secondary data obtained from literature studies, such as books, journals, articles and other sources of information that support research. The population of the study was the lecturers of the Faculty of Economics and Business Unjani who were permanent lecturers at the time this research was conducted, which were 46 people.Saturated sampling technique is used in taking samples, where the entire population is used as the research sample because the numbers are relatively not too many or too few [30].

\section{Research Instrument Test}

The instrument or measuring instrument used in this study has been tested for validity and reliability first. Validity test with Product Moment correlation, where each statement in the questionnaire is said to be valid when the calculated value of the Product Moment Correlation coefficient is greater than the Product Moment Correlation coefficient in the table (Valid $=r$ count $>r$ table). While the reliability test uses the Cronbachs Alpha method.

\section{Data analysis technique}

Descriptive statistical techniques are used to analyze the data by providing a description (picture) of the data that has been collected. Descriptive analysis is presented by calculating the mean or average of each dimension, then the mean value is interpreted in 3 categories as explained in the table below. This descriptive statistic is used in analyzing respondents' perceptions regarding work life balance and job satisfaction based on the data collected as they are. Categorization of mean value as follows:

Table 1. Interpretation of Mean Value Category

\begin{tabular}{cc}
\hline Mean Value & Description \\
\hline $1,00-2,33$ & Low \\
\hline $2,34-3,66$ & Middle \\
\hline $3.67-5,00$ & High \\
\hline
\end{tabular}

Source: Results of Data Processing

Furthermore, simple linear regression is also used for data analysis, where this analysis technique will produce predictions or estimates of how far the value of the dependent variable will change, if there is a change in the value of the independent variable [31]. Then followed by T-test to test the hypothesis and test the correlation coefficient of determination $\left(\mathrm{R}^{2}\right)$ to find out how big the percentage of influence given by the independent variable to the dependent variable. However, before linear 
regression analysis is carried out, the classical assumption test needs to be carried out first, including the normality test, linearity test and heteroscedasticity test.

\section{RESULT AND DISCUSSION \\ Descriptive Analysis of Respondents' Perceptions About Work Life Balance}

The following descriptive analysis is used to answer the first problem formulation regarding the perception of the lecturers regarding the work life balance of the lecturers at the Faculty of Economics and Business Unjani. The following are the results of statistical data processing to determine the work life balance of lecturers at the Faculty of Economics and Business Unjani:

Table 2. Respondents Work Life Balance

\begin{tabular}{lcc}
\hline \multicolumn{1}{c}{ Dimention } & Mean Value & Description \\
\hline Time balance & 4.02 & High \\
\hline Involvement balance & 3.60 & Middle \\
\hline Satisfaction balance & 4.30 & High \\
\hline
\end{tabular}

Source: Results of Data Processing

It is known from the data processing table, the dimension of satisfaction balance is the dimension with the highest average value (mean), which is 4.30 which is included in the high category. Means that the average respondent can achieve a good level of satisfaction both at work and during activities outside of work. In other words, every activity carried out by the lecturers can accommodate work needs, family needs or personal needs. When viewed in more detail on the statement items on the satisfaction balance dimension (attachment 2), the statement item with the highest mean of 4.57 is item 6, namely "My family supports my career and work", followed by the mean 4.24 is item 8 , namely "I am happy with my work life and personal life that I currently live" and the mean 4.11 is item 7, namely "I am satisfied with the feedback I have received so far in my work." This shows that the satisfaction balance of the lecturers is achieved, where the activities carried out can accommodate the needs of lecturers both as a worker, as part of a family and as a teacher personally.

In the dimension with a second order mean, namely time balance, with a mean value of 4.02 included in the high category, it means that the average lecturers can divide their time, both to complete work and to do other activities with family or personal activities, such as exercising or doing hobby. Although he works as a lecturer who has various tasks and responsibilities to complete, based on the answers, respondents stated that they can still divide their time between work and other activities. This can be due to the working hours of lecturers who do not have fixed working hours such as employees or other office staff. Lecturers tend to be able to adjust their working hours more flexibly according to the teaching schedule. Due to 
this flexibility, lecturers can seek a balance of time for work and other personal needs such as activities with family. When viewed in detail on the time balance dimension statement item (attachment 2), the statement item with the highest mean of 4.13 is item 1, namely "I have free time for family or friends outside of work", followed by the mean 4.07 is item 3, namely "I can divide my time well between work and personal life (such as: family events, doing hobbies, relaxing, etc.)" and the mean 3.89 is item 2, namely "I have enough time to do personal activities, such as doing hobbies, exercising, and so on. " This shows that the average teacher can divide his time for work and for his personal life, so that lecturers can still complete their work, but besides that they still have time for family and other personal matters.

The dimension with the third order mean, namely involvement balance, with a mean value of 3.60 is included in the medium category. This means that the psychological involvement of a teacher is not fully present in the activities being carried out.If we look in more detail at the statement items on the involvement balance dimension (attachment 2), the statement item with the highest mean of 4.11 is item 4, namely "I can enjoy being with my family", followed by the mean value of 3.11 is item 5 , namely "I don't think about work at the time. relax or on holiday." The mean on item 5 includes a medium average (not too high), this shows that even during holidays there are lecturers who think about their jobs, maybe work that has not been completed or that must be prepared immediately. So that even when they relax, psychologically the minds of some lecturers still thinking about their duties.From the three dimensions of the work life balance variable, it can be said that the work life balance of the lecturers of the Faculty of Economics and Business Unjani is in good condition, where with many activities and work as lecturers, they are still able to manage and divide the time to complete the work. and doing other activities outside of work, but if we look in more detail it is known that there are lecturers who still thinking about their works even when they are on vacation.

\section{Descriptive Analysis of Respondents' Perceptions of Job Satisfaction}

To answer the second problem formulation, which is to know the level of job satisfaction of the lecturers of the Faculty of Economics and Business Unjani, it is done by descriptive analysis. The following are the results of the assessment related to the level of job satisfaction of the lecturers of the Faculty of Economics and Business Unjani:

Table 3. The State of Respondents' Job Satisfaction

\begin{tabular}{lcc} 
Dimention & Mean Value & Description \\
\hline Psychological Factor & 4.26 & High \\
\hline Social Factor & 4.38 & High \\
\hline Physical Factor & 3.89 & High \\
\hline Financial Factor & 4.08 & High \\
\hline
\end{tabular}

Source: Results of Data Processing

http://ijstm.inarah.co.id 
From the data processing table, it appears that social factors have the highest mean of 4.38 which is included in the high category. This means that the average lecturers has a good working relationship or interaction between fellow members of the organization, both with fellow lecturers, superiors and staff at the Faculty of Economics and Business Unjani. When viewed in more detail the statement items on social factors (can be seen in Appendix 2), the statement with the highest mean of 4.46 is item 12, namely "I have a good relationship with co-workers", followed by the mean value of 4.37 is item 14, namely "I have a good relationship with coworkers". good relations with superiors", and the mean 4.33 is item 13, namely "I have a good relationship with the staff". From the average respondents' statements on these items, it shows that the state of the social factors of the lecturers of the Faculty of Economics and Business Unjani is in good condition, seen from the establishment of good relationships between members of the organization, both colleagues, superiors, and staff.The job satisfaction factor with a second order mean of 4.26 is the psychological factor, which is included in the high category. This means that the average respondent in this case the lecturers feels they have a job or profession that is in accordance with their interests, feels calm at work, and feels enthusiastic about their profession as a teacher.

When viewed in more detail the statement items on psychological factors (can be seen in appendix 2), the statement with the highest mean of 4.41 is item 9 , namely "The work I do is in accordance with my interests", followed by the mean value of 4.39 is item 11, namely "I enthusiastic about the work I do", and the mean 4.00 is item 10 "I feel comfortable in my work environment". The factor of job satisfaction with a mean of 4.08 is the financial factor, which is included in the high category. This means that the welfare of employees in this case the lecturers is in good condition, where the compensation received in the form of salaries and allowances is considered appropriate and can meet the needs, besides that there is an opportunity for better career advancement as lecturers is also one measure of achieving job satisfaction if from a financial point of view. When viewed in more detail the statement items on financial factors (can be seen in appendix 2), the statement with the highest mean of 4.30 is item 20 , namely "There is an opportunity for career advancement in my work", followed by the mean 4.02 is item 18, namely "The salary I receive in accordance with the demands of the work assigned to me", and the mean 3.93 is item 19, namely "The allowance provided is sufficient for my needs".

The factor of job satisfaction with a fourth mean of 3.89 is a physical factor, which is included in the high category indicating that the lecturers feel that the work space, circulation and air temperature are still quite good and quite comfortable for the lecturers. In addition, the facilities provided are also considered adequate and support the activities of the lecturers. When viewed in more detail the statement items on physical factors (can be seen in appendix 2), the statements with a mean of 4.00 are items 16 and 17 with the statement items "The condition of the work room provides a 
sense of comfort" and "My workplace has good air circulation and temperature. ", followed by a mean of 3.70 is item 15 , namely "The facilities in my workplace are adequate". Of the four dimensions in measuring the variable job satisfaction, it can be said that the job satisfaction of the faculty of economics and business faculty is classified as good. The lecturers achieve job satisfaction, both from social factors, psychological factors, financial factors and physical factors.

\section{Classic Assumption Test}

The classical assumption test is carried out as a condition that must be met for a simple regression analysis to be carried out, including:

\section{Normality Test}

Normality test with Shapiro Wilk test using IBM SPSS software version 24 for windows. The Shapiro Wilk test was used because the research sample was relatively small. The criteria for decision making are, if the significance value is $>0.05$ then the data is normally distributed, and vice versa if the significance value is $<0.05$ then the data is not normally distributed.

Table 4. Tests of Normality

\begin{tabular}{lcccccc}
\hline & \multicolumn{3}{c}{ Kolmogorov-Smirnov $^{\boldsymbol{a}}$} & \multicolumn{3}{c}{ Shapiro-Wilk } \\
\cline { 2 - 7 } & Statistic & $\boldsymbol{d} \boldsymbol{f}$ & Sig. & Statistic & $\boldsymbol{d f}$ & Sig. \\
\hline worklife_balance & .116 & 46 & .147 & .971 & 46 & .293 \\
\hline job_statification & .125 & 46 & .067 & .956 & 46 & .077 \\
\hline
\end{tabular}

a. Lilliefors Significance Correction

Source: Results of Data Processing

From the results of the normality test, the significant value for the work life balance variable is 0.293 and the job satisfaction variable is 0.077 . Both have a significant value of more than 0.05 , so from the normality test it is known that the data of both variables are normally distributed, so that the regression analysis method can be used because the assumption of normality has been met.

\section{Linearity Test}

To find out whether the variables in this study are linearly related or not, a linearity test was carried out. If the data is linear, then the use of linear regression analysis can be justified.

Table 5. Work Life Balance Linearity Test with Job Satisfaction ANOVA Table

\begin{tabular}{|c|c|c|c|c|c|c|c|}
\hline & & & $\begin{array}{l}\text { Sum of } \\
\text { Squares }\end{array}$ & $d f$ & $\begin{array}{l}\text { Mean } \\
\text { Square }\end{array}$ & $\boldsymbol{F}$ & Sig. \\
\hline \multirow{2}{*}{$\begin{array}{l}\text { job_statification* } \\
\text { worklife_balance }\end{array}$} & \multirow{2}{*}{$\begin{array}{c}\text { Between } \\
\text { Groups }\end{array}$} & (Combined) & 566.224 & 13 & 43.556 & 2.649 & .012 \\
\hline & & Linearity & 347.609 & 1 & 347.609 & 21.141 & .000 \\
\hline
\end{tabular}




\begin{tabular}{cccccc}
$\begin{array}{c}\text { Deviation } \\
\text { from } \\
\text { Linearity }\end{array}$ & 218.616 & 12 & 18.218 & 1.108 & .387 \\
\hline Within Groups & 526.145 & 32 & 16.442 & & \\
\hline Total & 1092.370 & 45 & & & \\
\hline
\end{tabular}

Source: Results of Data Processing

The results of the linearity test show that the regression line of the work-life balance variable $(\mathrm{X})$ with job satisfaction $(\mathrm{Y})$ has a significant value of $0.387>0.05$, thus the work-life balance variable has a linear relationship with job satisfaction.

\section{Heteroscedasticity Test}

Heteroscedasticity test was carried out to see the relationship between the independent variables and their residuals, this test was carried out using the Spearman Rank correlation method.

Table 6. Heteroscedasticity Test

Correlations

\begin{tabular}{|c|c|c|c|c|}
\hline & & & & standardized \\
\hline & & & worklife_balance & Residual \\
\hline Spearman's & worklife_balance & Correlation & 1.000 & -.010 \\
\hline rho & & Coefficient & & \\
\hline & & Sig. (2-tailed) & . & .946 \\
\hline & & $N$ & 46 & 46 \\
\hline & Unstandardized & Correlation & -.010 & 1.000 \\
\hline & Residual & Coefficient & & \\
\hline & & Sig. (2-tailed) & .946 & . \\
\hline & & $N$ & 46 & 46 \\
\hline
\end{tabular}

Source: Results of Data Processing

From the data processing table, the significance value of the $\mathrm{X}$ variable is $0.946>0.05$, indicating that the regression model obtained is free from heteroscedasticity cases.

\section{4. $\quad$ Simple Linear Regression Analysis}

The following simple linear regression analysis was carried out to answer the third problem formulation in this study. This analysis was processed with IBM SPSS version 24, the following output was obtained:

Table 7. Linear Regression Test

Coefficients

Coefficients $^{a}$

\begin{tabular}{llllll}
\hline & & Unstandardized & Standardized & & \\
& Coefficients & Coefficients & & Si \\
\cline { 2 - 4 } Model & B & Std. Error & Beta & &
\end{tabular}


International Journal Of Science, Technology \& Management

1 (Constant) $\quad 24.189 \quad 5.780 \quad 4.185 \quad .0$

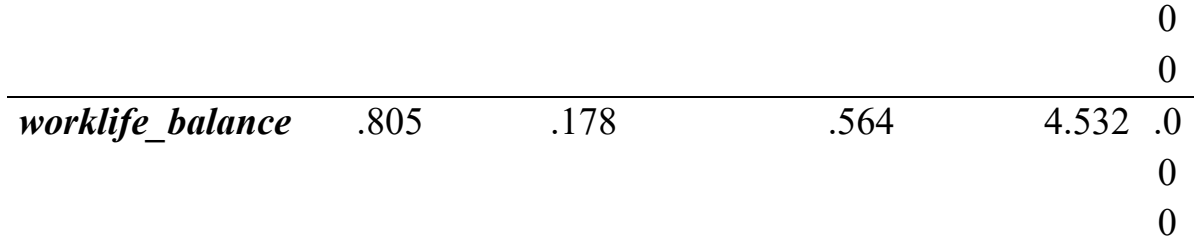

a. Dependent Variable: job_statification

Source: Results of Data Processing

The simple linear regression equation obtained from the table above is as follows:

$$
\mathrm{Y}=\mathbf{2 4 , 1 8 9}+\mathbf{0 . 8 0 5} \mathrm{X}
$$

The regression equation shows that work life balance has an effect on job satisfaction.

The following is an explanation of the regression equation:

1. The constant (a) $=24,189$ indicates that if the independent variable (x) namely work-life balance is 0 (zero), then job satisfaction is worth 24,189 . In other words, the dependent variable, namely job satisfaction without being influenced by the independent variable, has a value of 24,189 .

2. Regression coefficient (b) $=0.805$. The regression coefficient is positive (unidirectional), meaning that if the work life balance variable is getting better or has increased by one unit, then job satisfaction has also increased by 0.805 .

$\mathrm{T}$ test is used for hypothesis testing, the use of a significant level $(\alpha)$ of $5 \%, \mathrm{db}=$ $46-2=44$, the $t$ table value for the two-party test is obtained $=-2015$ and 2015 . Meanwhile, from data processing with IBM SPSS version 24 for windows, the value of $\mathrm{t}$ count $=4,532$. According to the criteria, the $\mathrm{T}$ test where the $\mathrm{t}$ value is $4.532>\mathrm{t}$ table 2,015 , then Ho is rejected or H1 is said to be accepted. This means that from the hypothesis test, it is found that work-life balance has a positive effect on job satisfaction for the lecturers of the Faculty of Economics and Business Unjani.

From the regression analysis also obtained the value of the coefficient of determination shown by the value of R Square in the following table:

Table 8. Coefficient of Determination

Model Summary

\begin{tabular}{lcccc}
\hline Model & $\boldsymbol{R}$ & $\boldsymbol{R}$ Square & $\begin{array}{c}\text { Adjusted } \boldsymbol{R} \\
\text { Square }\end{array}$ & $\begin{array}{c}\text { Std. Error of } \\
\text { the Estimate }\end{array}$ \\
\hline 1 & $.564^{\mathrm{a}}$ & .318 & .303 & 4.114 \\
\hline
\end{tabular}

a. Predictors: (Constant), worklife_balance

Source: Results of Data Processing

The coefficient of determination (R2) measures how much the independent variable can explain the dependent variable. Based on the data processing table, it is known that R Square is 0.318 or $31.8 \%$. So it can be said that work-life balance has an 
effect of $31.8 \%$ on teacher job satisfaction, while the remaining $68.2 \%$ is influenced by variables that are not used and are not examined in this study.

\section{CONCLUSION AND SUGGESTION Conclusion}

From the discussion in the previous chapter, it can be concluded:

1. The work life balance owned by the lecturers of the Faculty of Economics and Business Unjani is in good condition, where there are many activities and work as lecturers but they are still able to manage and divide time to complete work and carry out other personal activities, but If we look in more detail from the respondents' answers, there are lecturers who still think about work even though they are on vacation.

2. Job satisfaction of the lecturers of the Faculty of Economics and Business Unjani is classified as good, where the lecturers achieve job satisfaction, both in terms of social factors, psychological factors, financial factors and physical factors.

3. Based on the results of data processing, it can be concluded that work life balance has a positive effect on job satisfaction for lecturers at the Faculty of Economics and Business Unjani. The value of the determinant coefficient is $31.8 \%$, which means that the job satisfaction of the lecturers of the Faculty of Economics and Business Unjani of $31.8 \%$ is influenced by work life balance, while the remaining $68.2 \%$ is influenced by other variables not examined in this study.

\section{Suggestion}

This research can be deepened by adding other variables that support the job satisfaction variable and have not been used in this study. Besides that, it can also be done by setting more specific research objects, such as researching specifically for female workers or workers with a certain age range. If continuing research with the same object of research, namely lecturers, it is necessary to pay attention to lecturers who have structural positions and ordinary lecturers (not structurally positioned) because of course they have different workloads. By conducting these studies, knowledge about work-life balance and job satisfaction becomes deeper and wider.

\section{REFERENCES}

[1] Hudson Resourcing. (2005). 'The case for work/life balance: closing the gap between policy and practice'. Available on www.hudson.com.

[2] Saina, I., Pio, R., \& Rumawas, W. (2016). Pengaruh Worklife Balance Dan Kompensasi Terhadap Kinerja Karyawan Pada Pt Pln (Persero) Wilayah Suluttenggo Area Manado. Jurnal Administrasi Bisnis UNSRAT, 4(3), 1-9.

[3] Mathis Robert 1., dan John H. Jackson. (2011). Human resource management. New York: South-Western Cengage Learning. 
[4] Ramadhani, M. (2013). 'Analisis pengaruh keseimbangan kehidupan-kerja terhadap kesuksesan karir (studi pada karyawan PT. asuransi jiwa generali indonesia)'. Jurnal FEB Universitas Brawijaya Malang.

[5] Nurendra, A. M., \& Saraswati, M. P. (2016). Model peranan work life balance, stres kerja dan kepuasan kerja pada karyawan. Humanitas, 13(2). 84-94. https://doi.org/10.1017/CBO978110741532 4.004.

[6] Delecta, P. (2011). 'Work life balance'. International Journal of Current Research. Vol. 33, Issue, 4, pp.186-189.

[7] Vyas, A., \& Shrivastava, D. (2017). Factors Affecting Work Life Balance - A Review. Pacific Business Review International, 9(7), 194-200.

[8] Lumunon, R. R., Sendow, G. M., \& Uhing, Y. (2019). Pengaruh Work Life Balance, Kesehatan Kerja Dan Beban Kerja Terhadap Kepuasan Kerja Karyawan PT. Tirta Investama (Danone) AQUA Airmadidi. Jurnal Ekonomi, Manajemen, Bisnis, Dan Administrasi (EMBA), 7(4), 4671-4680.

[9] Moore, F. (2007). 'Work-life balance: contrasting managers and workers in an MNC'. Employee Relations. 29(4), 385-399.

[10] Rifadha, M. U. F., \& Sangarandeniya, Y. M. S. W. V. (2015). The impact of work life balance on job satisfaction of managerial level employees of people's bank, (head $\begin{array}{llllll}\text { office), Sri Lanka. Journal of Management, } & 12(1),\end{array}$ https://doi.org/10.4038/jm.v12i1.7583.

[11] McDonald, P., dan Bradley, L.M. (2005). 'The case for work/life balance: closing the gap between policy and practice'. 20:20 Series, 15 .

[12] Paleksic, V., et al. (2017). 'The relationship between personality traits and job satisfaction of teachers'. Scripta Medica. 48(1)11-17.

[13] Wen, C. T. Y., Muthuveloo, R., \& Ping, T. A. (2018). Factors Influencing Job Satisfaction: A Perspective of Millennials in Malaysia Multinational (MNC) Companies. An International Journal, 10(1), 2025.

[14] Hasibuan, Malayu S.P. (2015). Manajemen Sumber Daya Manusia. Edisi Revisi. Jakarta : PT. Bumi Aksara.

[15] Vokić, Nina Pološki dan Tomislav Hernaus. (2015). 'The triad of job satisfaction, work engagement and employee loyalty - the interplay among the concepts'. EFZG Working Paper Series. 15(7). 1-13.

[16] Robbins, S. P. dan Judge, T. A. (2015). Perilaku organisasi. Edisi 16. Jakarta : Salemba Empat

[17] Hasibuan, Malayu S.P. (2015). Manajemen Sumber Daya Manusia. Edisi Revisi. Jakarta : PT. Bumi Aksara.

[18] Luthans, F. (2006). Organizational behaviour. McGraw-Hill Companies, Inc.

[19] Sutrisno, Edy. (2010). Manajemen Sumber Daya Manusia. Jakarta : Kencana Prenada Media Group.

[20] Moedy, D. M. R. (2013). Analisis work-life balance, keinginan untuk meninggalkan organisasi, kepenatan (burnout) dan kepuasan kerja pada dosen Universitas Atma Jaya Yogyakarta (Doctoral dissertation, UAJY).

[21] Goyal, M., dan Arora, S. (2012), 'Harnessing work : family life balance among teachers in educational institutions'. International Journal of Applied Services Marketing. 
[22] Qodrizana, Diah L., Musadieq, Mochamad Al. (2018). 'Pengaruh work life balace terhadap kepuasan kerja (studi pada karyawan perempuan yayasan insan permata tunggulwulung kota malang)'. Jurnal administrasi bisnis. Vol. 60.

[23] Ganapathi, I Made Devan. dan Gilang, Alini. (2016). 'Pengaruh work life balance terhadap kepuasan kerja karyawan (studi pada PT bio farma persero)'. E-Proceeding of Management. Vol. 3, page 506.

[24] Parimita, Widya. dan Widyastuti, Umi. (2015). "Pengaruh work life balance dan stres kerja terhadap kepuasan kerja pada tenaga pendidik (dosen) fakultas ekonomi universitas negeri jakarta". Jakarta : Universitas Negeri Jakarta.

[25] Sumaiti, R. S. A. (2010). 'The work life balance and job satisfaction in oil and gas organisations in the UAE context'. Bisnis Universitas British Dubai (BUiD) Digital Repository.

[26] McDonald, P., dan Bradley, L.M. (2005). 'The case for work/life balance: closing the gap between policy and practice'. 20:20 Series, 15.

[27] Sutrisno, Edy. (2010). Manajemen Sumber Daya Manusia. Jakarta : Kencana Prenada Media Group.

[28] Sugiyono. (2013). Metode penelitian bisnis. Bandung: Alfabeta.

[29] Sugiyono. (2013). Metode penelitian pendekatan kuantitatif, kualitatif, dan $R \& D$ Bandung : Alfabeta

[30] Sugiyono. (2013). Metode penelitian pendekatan kuantitatif, kualitatif, dan $R \& D$ Bandung : Alfabeta

[31] Sugiyono. (2013). Metode penelitian pendekatan kuantitatif, kualitatif, dan $R \& D$ Bandung : Alfabeta 